\title{
New records on cyclomorphosis in the marine eutardigrade Halobiotus crispae (Eutardigrada: Hypsibiidae)
}

\author{
Nadja MØBJERG $^{1}{ }^{1} *$, Aslak JØRGENSEN ${ }^{2}$, Jette EIBYE-JACOBSEN ${ }^{3)}$, Kenneth AGERLIN HALBERG ${ }^{1,3)}$ \\ Dennis PERSSON ${ }^{1,3)}$ and Reinhardt MØBJERG KRISTENSEN ${ }^{3)}$ \\ ${ }^{1)}$ Department of Molecular Biology, August Krogh Building, University of Copenhagen, Universitetsparken 13, DK-2100 \\ Copenhagen, Denmark \\ ${ }^{2)}$ DBL - Centre for Health Research and Development, University of Copenhagen, Jægersborg Allé 1D, DK-2920 Charlottenlund, \\ Denmark \\ ${ }^{3)}$ Natural History Museum, Zoological Museum, University of Copenhagen, Universitetsparken 15, DK-2100 Copenhagen, Denmark \\ *e-mail corresponding author: nmobjerg@aki.ku.dk
}

\begin{abstract}
Halobiotus crispae is a marine eutardigrade belonging to Hypsibiidae. A characteristic of this species is the appearance of seasonal cyclic changes in morphology and physiology, i.e. cyclomorphosis. Halobiotus crispae was originally described from Nipisat Bay, Disko Island, Greenland. The present study investigates the distribution of this species and describes the seasonal appearance of cyclomorphic stages at the southernmost locality, Vellerup Vig in the Isefjord, Denmark. Our sampling data indicate that the distribution of $\mathrm{H}$. crispae is restricted to the Northern Hemisphere where we now have found this species at seven localities. At Vellerup Vig data from sampling cover all seasons of the year and all of the originally described cyclomorphic stages have been found at this locality. However, when comparing the lifecycles of $\mathrm{H}$. crispae at Nipisat Bay and Vellerup Vig, profound differences are found in the time of year, as well as the period in which these stages appear. Noticeably, at Nipisat Bay the pseudosimplex 1 stage is a hibernating stage occurring during the long Arctic winter. In contrast, at Vellerup Vig, this stage appears during the summer. Thus, while pseudosimplex 1 seems to be an adaptation to withstand low temperatures in Greenland, this stage possibly enables the animal to tolerate periods of oxygen depletion and heat stress during the Danish summer. Moreover, a characteristic of the Danish population is the presence of a prolonged pseudosimplex 2 stage. The environmental or endogenous signals underlying the transition between different stages remain unknown. In addition, we report the genetic diversity and phylogenetic position of $\mathrm{H}$. crispae based on the first molecular data obtained from this species. Our molecular data confirm that $\mathrm{H}$. crispae from Greenland and Denmark are in fact the same species. Thus, the observed life cycle changes occur within a species and do not represent life cycle variation between different species. In addition, our molecular data suggest that Halobiotus has evolved within Isohypsibius. Further investigations on the lifecycle of members of the Halobiotus genus as well as other members of the Hypsibiidae is needed in order to establish whether cyclomorphosis is i) a general theme among members of Hypsibiidae or ii) an autapomorphy for Halobiotus.
\end{abstract}

Key words: cyclomorphosis, distribution, Eutardigrada, genetic diversity, life cycle, phylogenetic position

\section{INTRODUCTION}

Although seasonal cyclic changes in morphology and physiology have been suggested for other tardigrades (Rebecchi \& Bertolani 1994; Hansen \& Katholm 2002; Guidetti et al. 2006), Halobiotus crispae Kristensen, 1982 remains the only tardigrade for which cyclomorphosis has been clearly established (Kristensen 1982; Kinchin 1994). The presence of cyclomorphosis, which has been suggested for the glacier tardigrades Hypsibius klebelsbergi Mihelčič, 1959 and Hypsibius janetscheki Ramazzotti, 1968, has recently been questioned (Dastych 2004). Cyclomorphosis in H. crispae is characterised by changes within the individual, and $H$. crispae from the type locality at Nipisat Bay (Disko Island, Greenland) was found in four distinct stages (Kristensen 1982). 1. The active stage characterised by fully developed gonads and bucco-pharyngeal apparatus with six peribuccal sensory organs. Animals in this stage have an open mouth and cloaca and furthermore posses long claws. 2. A simplex or moulting stage lacking stylets and placoids. The mouth is closed in this stage and lacks peribuccal sensory organs. 3 . The pseudosimplex 1 stage or hibernation stage is characterised by a conspicuous double cuticle. The thick outer cuticle is homologous with the old simplex cuticle, while the thinner inner cuticle is a new formation and bears a new set of claws. The mouth and cloaca are closed by cuticular thickenings. Noticeably, the pharyngeal bulb is only lined by straight cuticle (bar shaped placoids), macroplacoids and microplacoids are not present (Kristensen 1982; Eibye-Jacobsen 1997, 2001). Furthermore the stylets and stylet supports are thin. Gonads are degenerated in this stage and sex determination is therefore not possible. 4. The pseudosimplex 2 stage is a sexually ripening stage, which corresponds to the pseudosimplex 1 stage without the outer cuticle. The mouth and cloaca are open in this stage. The claws of pseudosimplex 2 are small when compared to specimens in the active stage. The aberrant claws and pharyngeal appa- 


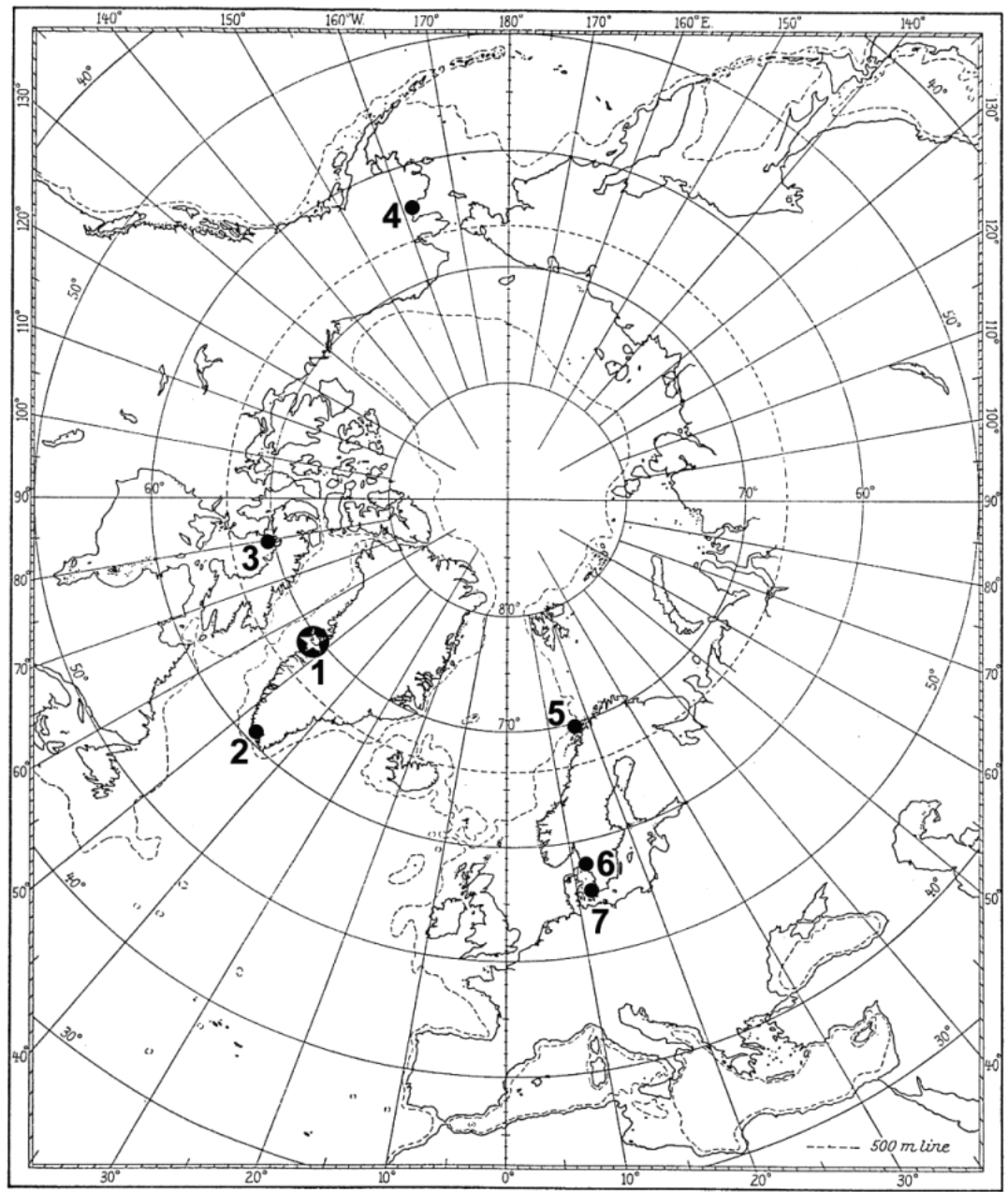

Fig. 1. Distribution of Halobiotus crispae. 1: The type locality at Nipisat, Disko Island, Greenland. 2: Ikka Fjord, Greenland. 3: Igloolik, Arctic Canada. 4: Fairbanks, Alaska, USA. 5: Grindøy, Tromsø, Norway. 6: Kristineberg, Sweden. 7: Vellerup Vig, Denmark.

ratus of the pseudosimplex stages would make species determination of these stages impossible if the transition between the pseudosimplex and active stages were not directly observed.

In Copenhagen, H. crispae has been used as a model organism of tardigrade morphology and ultrastructure and our studies in this species cover e.g. the Malpighian tubules, the pharynx and development of this animal (Møbjerg \& Dahl 1996; Eibye-Jacobsen 1997, 2001). Therefore this tardigrade has been sampled not only at the type locality at Nipisat Bay (Disko Island, Greenland) but also at Vellerup Vig in the Isefjord (Denmark) at regular intervals for almost two decades.

In the present study the seasonal appearance of cyclomorphic stages at the southernmost locality, Vellerup Vig, is compared to Nipisat Bay and the finding of $H$. crispae at other localities on the Northern Hemisphere is reported. Furthermore, we have reinvestigated the socalled Halobiotus stenostomus (Richters, 1908) from Ærø (Jørgensen \& Kristensen 2004) both with morphological and molecular techniques.
Whether cyclomorphosis is unique to Halobiotus within Hypsibiidae is still an open question (Kristensen 1982). Therefore, the first molecular data obtained from this species are presented and the phylogenetic position of $H$. crispae within the Hypsibiidae is discussed in order to direct possible future investigations on the presence of cyclomorphosis in tardigrades.

\section{METHODS}

\subsection{Tardigrade sampling}

Halobiotus crispae has been found in bottom samples collected at seven different localities during routine sampling for marine tardigrades in tidal and subtidal habitats. Samples were collected with a mini van Veengrab or by diving. In most cases the samples were freshwater shocked before being sorted. The seven localities are shown in figure 1 and include the type locality at Nipisat Bay (Greenland); Vellerup Vig, Denmark (20 years regular collections); Kristineberg, Sweden (collected intertidally June 1986); Grindøy, 
Tab. 1. The taxon and gene sampling. Most of the sequences from the four molecular loci represent original data. Only the three 18S rRNA sequences from Halobiotus crispae Ærø (previously regarded as H. stenostomus), Thulinius stephaniae and Ramazzottius oberhaeuseri have been extracted from GenBank.

\begin{tabular}{lllllr}
\hline \multirow{2}{*}{ Species } & Locality & & \multicolumn{2}{c}{ GenBank Accession Number } \\
\cline { 3 - 5 } & & 18S rRNA & 28S rRNA & COI & ITS2 \\
\hline Halobiotus crispae & Nipisat, Greenland & EF620401 & EF620411 & EF620412 & EF620420 \\
Halobiotus crispae & Vellerup Vig, Denmark & EF620402 & EF620409 & EF620413 & EF620421 \\
Halobiotus crispae & Erø, Denmark & AY582121 & EF620408 & EF620414 & EF620422 \\
Isohypsibius granulifer & Nivå, Denmark & EF620403 & EF620405 & - & EF620424 \\
Isohypsibius prosostomus & Nivå, Denmark & EF620404 & EF620406 & EF620416 & EF620423 \\
Thulinius stephaniae & Sinai, Egypt/GenBank & AF056023 & EF620407 & EF620417 & EF620425 \\
Ramazzottius oberhaeuseri & Nivå, Denmark & AY582122 & EF620410 & EF620418 & EF620419 \\
\hline
\end{tabular}

Tromsø, Norway (collected subtidally July 1981); Igloolik, Arctic Canada (collected in a melt water pond June 1989); Fairbanks, Alaska, U.S.A. (collected March 1973 ) and the recently described Ikait columns from the Ikkafjord, Greenland (collected in ikait snow at a depth of 2 meters August 1997). Voucher specimens from the localities are deposited in the collection of R.M. Kristensen, the Natural History Museum in Copenhagen.

Collections at Vellerup Vig in the Isefjord (Denmark) have been carried out at regular intervals from 1983 to 2007. At this locality H. crispae is found in bottom samples at subtidal depths of $1.5 \mathrm{~m}$ to $3 \mathrm{~m}$. The locality is characterised by the presence of the blue mussel Mytilus edulis (Linnaeus, 1758), the seagrass Zostera marina (Linnaeus, 1753) and the algae Ahnfeltia plicata (Hudson, 1762) and Sphacelaria cirrosa (Roth) C. Agardh, 1824. Halobiotus crispae is found in connection with the haptera of algae on mussels and stones, primarily living on the brown filamentous algae $S$. cirrosa. At the type locality Nipisat Bay the species was originally found on the brown algae Sphacelaria arctica Harvey, 1858. With the exception of the locality at Ikka Fjord (Southwest Greenland) the sediment at the sampling localities consisted of fine sand, pebbles and small stones many times in connection with $M$. edulis. At Ikka Fjord, however, the sediment consisted of so-called ikait snow, which was found on top of the largest submarine columns of ikaite tufa (up to $18 \mathrm{~m}$ ) formed over submarine springs in the Fjord. Ikaite is a metastable hexahydrate of calcium carbonate $\left(\mathrm{CaCO}_{3}, 6 \mathrm{H}_{2} \mathrm{O}\right)$ formed by carbonate precipitation in the cold-water, high $\mathrm{pH}$ and high phosphate environment characterising Ikka Fjord (Buchardt et al. 1997).

The salinity at the different localities varies greatly from extremities of $32 \%$ at the type locality (Kristensen 1982 ) to $2 \%$ (melt water pond) at Igloolik, Arctic Canada (Jørgensen \& Kristensen 1991). The salinity at Vellerup Vig is approximately 18-20 \%o (Rasmussen 1973).

\subsection{Microscopy}

Formalin fixed specimens from Vellerup Vig were used for Normarski light microscopy. Polyvinyl-lactophenol and glycerol were used for permanent preserva- tion of specimens. For scanning electron microscopy tardigrades were fixed in trialdehyde (Kalt \& Tandler 1971; Kristensen 1982), postfixed in $1 \% \mathrm{OsO}_{4}$ in $0.1 \mathrm{M}$ cacodylate buffer ( $\mathrm{pH} 7.2$ ), dehydrated through ethanol, $\mathrm{CO}_{2}$-critical point dried, and coated with gold. Specimens were examined in JEOL JSM-840 and JEOL JSM6335F Field Emission scanning electron microscopes.

\subsection{Molecular methods and data analysis}

Approximately ten specimens for each species (Tab. 1) were pooled in the DNA extractions. Ramazzottius oberhaeuseri (Doyère, 1840) was used as outgroup. 18S rRNA sequences from specimens from Ærø firstly attributed to H. stenostomus (AY582121; Jørgensen \& Kristensen 2004), but now attributed to $H$. crispae, Thulinius stephaniae (Pilato, 1974) (AF056023; Garey et al. 1999) and R. oberhaeuseri (AY582122; Jørgensen $\&$ Kristensen 2004) have been extracted from GenBank. COI for Isohypsibius granulifer Thulin, 1928 Nivå was not obtained; this species is verified by R. Bertolani and the investigation of the type material.

We used both live and stored (dried out) material and the specimens were carefully grinded using the STE-buffer DNA extraction method (Maniatis et al. 1982). The primers for the nuclear $18 \mathrm{~S}$ rRNA (Giribet et al. 1996) and 28S rRNA (Markmann 2000) genes, the mitochondrial cytochrome oxidase subunit I (COI; Folmer et al. 1994) and the nuclear ITS2 (DeJong et al. 2001) genes were used for both PCR amplifications and direct sequencing. For details on the PCR reaction, DNA sequencing and phylogenetic analyses please consult Jørgensen et al. 2007 (this volume).

\section{RESULTS}

\subsection{Distribution}

Our regular samplings for tardigrades around the world have revealed Halobiotus crispae at six additional localities (Fig. 1). These localities are all on the Northern Hemisphere. With the exception of the southernmost locality Vellerup Vig (Denmark) and the ikait columns of the Ikka Fjord (Greenland), the animals found were all in the active stage. In contrast, specimens of $\mathrm{H}$. crispae taken from the Ikka Fjord in August 1997 were in the pseudosimplex 2 stage. All four cyclomorphic 

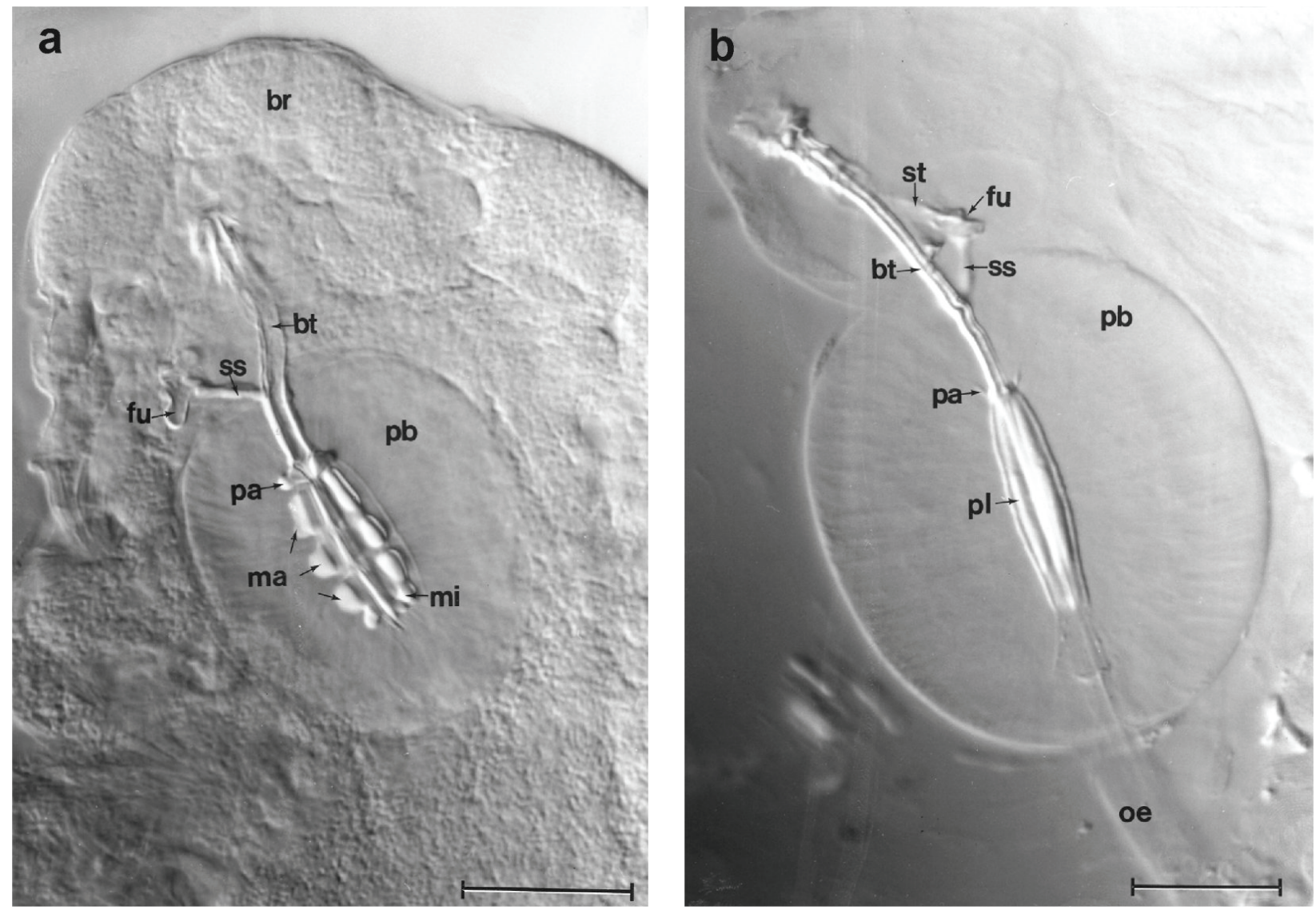

Fig. 2. Light microscopy, Normarski-technique of the bucco-pharyngeal apparatus of Halobiotus crispae in active and pseudosimplex 2 stages. Specimens from Vellerup Vig (Polyvinyl-lactophenol). a: The pharyngeal bulb of an active animal. Note the characteristic macro- and microplacoids. b: The pharyngeal bulb from an animal in pseudosimplex 2 . The bulb is lined by straight cuticle (bar-shaped placoids) and macro- and microplacoids are absent. br: brain, bt: buccal tube, fu: furca, ma: macroplacoid, mi: microplacoid, oe: esophagus, pa: pharyngeal apophysis, pb: pharyngeal bulb, pl: placoid, ss: stylet support, st: stylet. Scale bars: $\mathrm{a}=$ $30 \mu \mathrm{m}, \mathrm{b}=20 \mu \mathrm{m}$.

stages, including the normal moulting stage (the simplex stage), have been found at Vellerup Vig.

\subsection{Cyclomorphosis at Vellerup Vig, Denmark compared with Nipisat Bay, Greenland}

In the following we report the appearance of cyclomorphic stages at Vellerup Vig and compare the life cycle of Halobiotus crispae at this locality with the originally described seasonal occurrence of cyclomorphic stages at Nipisat Bay (Kristensen 1982). As pointed out below, we found no morphological characteristics that could distinguish the specimens from Vellerup Vig from the originally described population at Nipisat Bay. As holds for the Greenlandic population (Kristensen 1982) a common characteristic of the pseudosimplex stages at Vellerup Vig is the presence of a modified bucco-pharyngeal apparatus (Figs 2 and 3a-d). The bar-shaped placoids and the presence of an apparently fully formed mouth ring in the pseudosimplex 2 stage (Fig. 2b) were already shown in the original description of $H$. crispae from Nipisat (Fig. 10 in Kristensen 1982). As in Nipisat, the six peribuccal sensory structures in pseudosimplex 2 (Fig. 3b) are retracted into the buccal cavity (Fig. 10a in Kristensen 1982). As holds for the Nipisat population the six sensory structures (ps) are clearly visible in the active stage (Fig. 3d; Figs 9 and 17 in Kristensen 1982). We found no difference in size or configuration of the claw system in the different stages between the two populations (Fig. 3e; Figs 4-6 in Kristensen 1982). A characteristic of pseudosimplex 2 and active stages of both populations is the presence of an open mouth and cloaca. Figure $3 \mathrm{f}$ depicts the open trilobed cloaca of an animal in the active stage from Vellerup Vig. In summary, the presence of cyclomorphosis in $H$. crispae is truly emphasised by the differences between the mouth region in the active and pseudosimplex 2 stages. These remarkable differences are similar in both populations.

Figure 4 shows the life cycle of $H$. crispae as described from the type locality (Fig. 4a) (Kristensen 1982) and from Vellerup (Fig. 4b). At Nipisat Bay the transformation into the pseudosimplex 1 stage is correlated with the first formation of ice in the Bay occurring in September-October. 

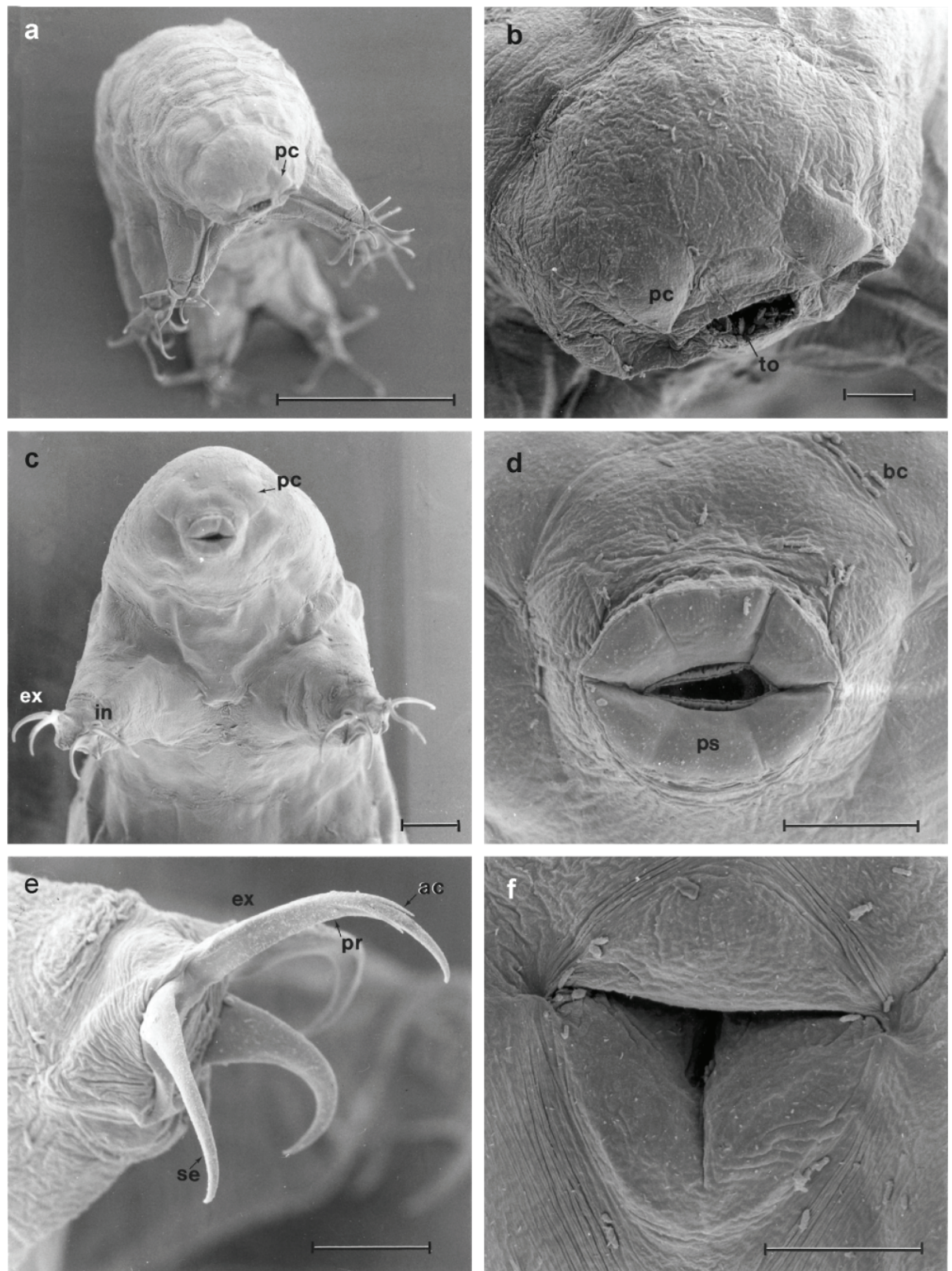

Fig. 3. SEM-investigation of Halobiotus crispae from Vellerup Vig in the active and pseudosimplex 2 stage. a: Pseudosimplex 2 with conspicuous papilla cephalica. The border of epidermis cells is visible beneath the single thin cuticle. b: Head of animal showed in picture a. The mouth is open and a new set of teeth is visible. The six peribuccal sense organs are retracted into the mouth cavity. c: Frontal view of animal in the active stage. d: Detail of mouth region of animal showed in picture c. The mouth opening is surrounded by peribuccal sense organs. Bacteria surround the region. e: The external double claw on the first pair of legs from an animal in the active stage. The double claw is divided into a primary branch with to accessory points and a secondary branch. f: The cloaca from the animal showed in picture c surrounded by bacteria. ac: accessory point, bc: bacteria, ex: external claw, in: internal claw, pc: papilla cephalica, pr: primary branch, ps: peribuccal sense organ, se: secondary branch, to: tooth. Scale bars: $a=100 \mu \mathrm{m}, \mathrm{b}$ $=10 \mu \mathrm{m}, \mathrm{c}=20 \mu \mathrm{m}, \mathrm{d}, \mathrm{e}, \mathrm{f}=10 \mu \mathrm{m}$. 


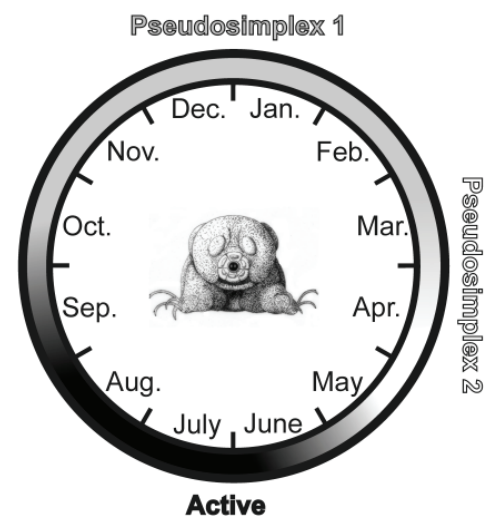

a. Nipisat, Greenland

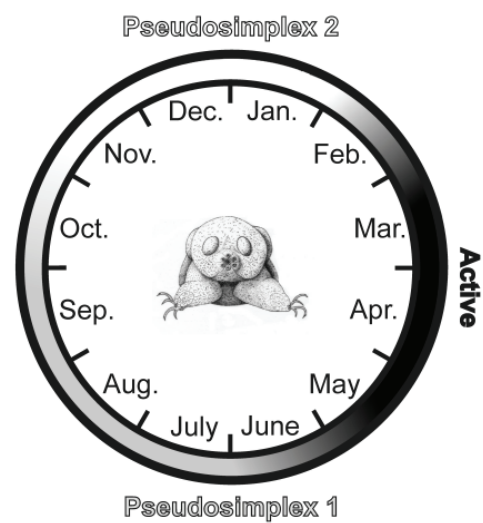

b. Vellerup, Denmark

Fig. 4. Cyclomorphosis in Halobiotus crispae. The seasonal occurrence of cyclomorphic stages. a: Nipisat Bay, Greenland. The drawing shows a frontal view of an animal in the active stage. b: Vellerup Vig, Denmark. The drawing shows a frontal view of an animal in the pseudosimplex 2 stage.

Tab. 2. The genetic diversity in COI and ITS2. Values below the diagonal are COI genetic diversity and above the diagonal ITS2 genetic diversity. The genetic diversity is calculated as $p$ distance.

\begin{tabular}{llcccccccc}
\hline & Species & \multicolumn{7}{c}{ Pairwise-distance } \\
& & 1 & 2 & 3 & 4 & 5 & 6 & 7 \\
\hline 1 & Halobiotus crispae from Nipissat & & 0.0000 & 0.0000 & 0.3611 & 0.3356 & 0.3340 & 0.1680 \\
2 & Halobiotus crispae from Vellerup & 0.0073 & & 0.0000 & 0.3611 & 0.3356 & 0.3340 & 0.1680 \\
3 & Halobiotus crispae from Ærø & 0.0098 & 0.0073 & & 0.3611 & 0.3356 & 0.3340 & 0.1680 \\
4 & Isohypsibius granulifer & - & - & - & & 0.3929 & 0.3784 & 0.1920 \\
5 & Isohypsibius prosostomus & 0.2268 & 0.2244 & 0.2293 & - & & - & 0.2287 & 0.1825 \\
6 & Thulinius stephaniae & 0.2195 & 0.2171 & 0.2195 & - & 0.2317 & & 0.1349 \\
7 & Ramazzottius oberhaeuseri & 0.2634 & 0.2634 & 0.2683 & - & 0.2610 & 0.2415 \\
\hline
\end{tabular}

Animals emerge from the pseudosimplex 1 outer cuticle as a pseudosimplex 2 stage when the ice thaws in April-May. This stage lasts for a very short period before the tardigrade moults (i.e., goes into the simplex stage) and enters the active stage in May-June. Exuvia with eggs are found at Nipisat in June-August. At Vellerup the pseudosimplex 1 stage appears in May-June and most animals stay in this stage throughout the Danish summer entering the pseudosimplex 2 stage around October (Fig. 4b). In Denmark, the pseudosimplex 2 stage is prolonged lasting for several months as compared to the very short period of 14 days to 1 month at Nipisat. The Danish population of $H$. crispae enter the active stage in February and exuvia with eggs have been observed from February-May. At Vellerup we have noted, that a small percentage (1-2\%) of the $H$. crispae population is in the active stage in the months that are dominated by the pseudosimplex stages.

\subsection{Genetic diversity and phylogenetic position of Halobiotus}

The differences between the life cycle of Halobiotus crispae at Nipisat Bay and Vellerup Vig could be explained by i) the presence of two different species, which can not be differentiated on the basis of morpho- logical characters or ii) a shift in life cycle within different populations of a single species. Therefore, we investigated the genetic diversity for the molecular loci COI and ITS2 between the two populations. The intraspecific genetic diversity in COI of $H$. crispae was $0.7 \%$ (Tab. 2). In addition, we found that the genetic distance between $H$. crispae and Halobiotus from Ærø (Denmark) was only $0.7 \%-1.0 \%$. These data strongly suggest that not only the two populations of $H$. crispae, but also Halobiotus from Ærø (Denmark) belong to the same species. The distance between Halobiotus and Isohypsibius was $22.4 \%-22.9 \%$ and between Halobiotus and Thulinius it was $21.7 \%-22.0 \%$. The sequence variation between Halobiotus and the outgroup Ramazzottius oberhaeuseri was $26.3 \%-26.8 \%$. No intrageneric genetic diversity of Halobiotus was found in ITS2. The genetic diversity in ITS2 between Halobiotus and Isohypsibius was 33.6\%-36.1\% and between Halobiotus and Thulinius $33.4 \%$. The sequence variation between Halobiotus and $R$. oberhaeuseri was $16.8 \%$. It was only possible to obtain a smaller and relatively conserved fragment of ITS2 from $R$. oberhaeuseri, which explains the low genetic diversity values of this species in table 2 .

Cyclomorphosis has been suggested for other tardigrades, e.g. in a species of Amphibolus (Rebecchi \& 
a

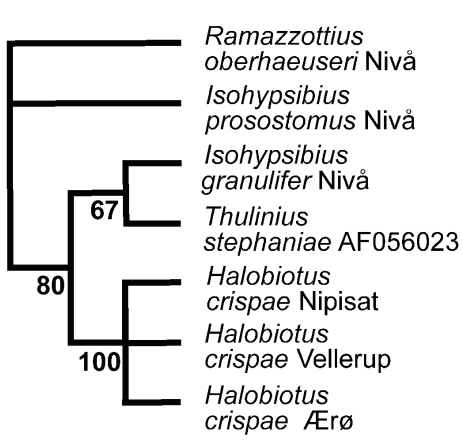

C

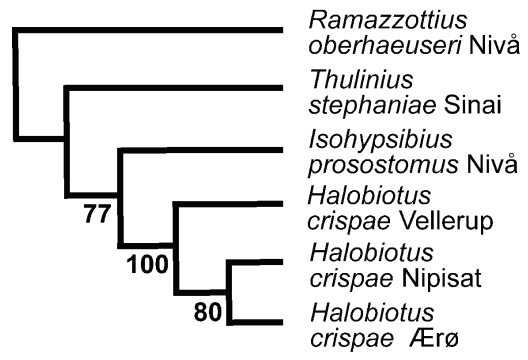

b $\quad 28 S$ rRNA

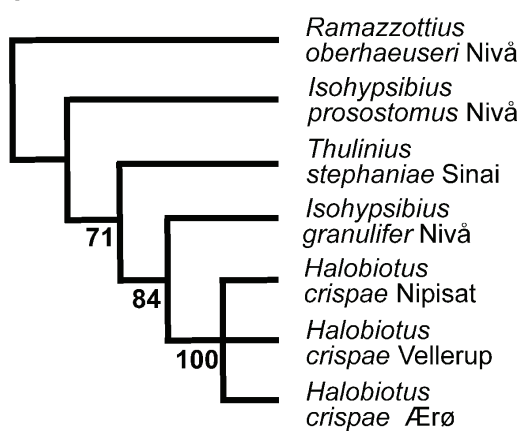

d

ITS2

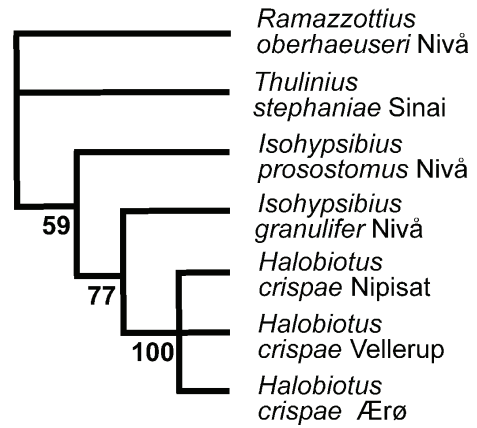

Fig. 5. The phylogenetic relationships of Halobiotus. a: The nuclear $18 \mathrm{~S}$ rRNA. b: The nuclear $28 \mathrm{~S}$ rRNA. c: The mitochondrial COI. d: The nuclear ITS2. The inferred cladograms are based on maximum parsimony and bootstrap values are presented at the supported nodes.

Bertolani 1994; Hansen \& Katholm 2002). Whether cyclomorphosis is unique for Halobiotus among the hypsibiid tardigrades or is present in the sister groups of this genus remains to be elucidated. In this study we bring data on the phylogenetic position of Halobiotus in order to establish sister group relations, which could direct further investigations on the presence of cyclomorphosis in Hypsibiidae. Our data on four molecular loci suggest that Halobiotus has evolved within Isohypsibius (Fig. 5). The analyses of 18S, 28S and ITS2 (with two Isohypsibius species) showed a paraphyletic Isohypsibius.

\section{DISCUSSION}

In the present study we report the currently known distribution of $H$. crispae. A wide distribution, as the holarctic distribution of $H$. crispae, is a common feature of other members of Hybsibiidae. Within the Isohypsibius genus approximately one fourth of the species are present on two or more continents (McInnes 1994).

In $H$. crispae four distinct stages appear during cyclomorphosis (Kristensen 1982). One stage - the simplex stage is a normal moulting stage also known from other tardigrades. Thus, three true cyclomorphic stages are present; the active stage, pseudosimplex 1 and pseudosimplex 2. While in the active stage $H$. crispae reproduces. The pseudosimplex 1 stage is formed from the active stage by an incomplete moult, in which the sclerified parts of the bucco-pharyngeal apparatus are shed but the old cuticle surrounding the animal is retained. Pseudosimplex 2 lacks the outer encysting cuticle and as the mouth and cloaca are open the aberrant pseudosimplex bucco-pharyngeal apparatus is functional in this stage (Figs 2 and 3).

The pseudosimplex 1 stage is comparable to the cysts found in Amphibolus and Dactylobiotus (see Rebecchi \& Bertolani 1994; Hansen \& Katholm 2002; Guidetti et al. 2006). In contrast to pseudosimplex 1 of $H$. crispae the cysts found in these last genera are surrounded by 2-3 layers of cuticle and furthermore, differently from the cysts, the pseudosimplex 1 stage is distinctly characterised by being capable of movement (Kristensen 1982). Pseudosimplex 2 cannot be regarded as a cyst or dormant stages as it lacks the outer encysting cuticle and the mouth and cloaca are open (Figs 3a and $3 b)$.

The present study puts focus on the seasonal appearance of cyclomorphic stages at the southernmost locality, Vellerup Vig in Denmark as compared to the type locality at Nipisat Bay in Greenland. Profound differences were found in the time of year, as well as the period in which these cyclomorphic stages appear at the two localities. While the active stage is present during the Greenlandic summer, this stage is found during late winter and the spring months in Denmark (Fig. 4). It is worth noting, that environmental parameters, such as temperature, are comparable during these different seasons at the two localities. The pseudosimplex 1 stage is 
a winter stage in Greenland, while this stage appears during the summer in Denmark. Our preliminary and unpublished data suggest that pseudosimplex 1 is the only cyclomorphic stage at which $H$. crispae is capable of freezing (cryobiosis?). Thus, while pseudosimplex 1 seems to be an adaptation to withstand low temperatures in Greenland, this stage possibly enables the animal to tolerate periods of oxygen depletion and heat stress during the Danish summer. The pseudosimplex 2 stage, which only appears at Nipisat Bay for a very short period during spring, has a prolonged appearance at Vellerup Vig and in Denmark this stage is the actual "over wintering" stage. The physiological relevance of this prolonged appearance remains unknown. In addition, the environmental or endogenous signals underlying the transition between different stages remain to be investigated. Halobiotus crispae is capable of tolerating large shifts in salinities as evidenced by the salinities encountered at the different localities. Our data on the H. crispae localities suggest that heat stress may be the external parameter setting the limits for the distribution of this tardigrade. As indicated above, another abiotic factor, perhaps limiting distribution in a southern direction, is the rapid oxygen depletion occurring at low depths in the marine environment during warm summer months. Future investigations will be directed at elucidating the osmotic and heat stress tolerance of the active stage as compared to the pseudosimplex stages of this tardigrade.

Cyclomorphosis could be present in other hypsibiid species (Kristensen 1982) and the possibility that cyclomorphic stages of a given species have been described as different species is certainly a possibility. Our molecular data show that Halobiotus have evolved within the paraphyletic Isohypsibius and further investigations on the life cycle of members of the Halobiotus genus as well as other members of the Hypsibiidae are needed in order to establish whether cyclomorphosis is a general theme among members of Hypsibiidae or an autapomorphy for Halobiotus. Cyclomorphosis could have developed in H. crispae as an adaptation to life in the subtidal zone characterised by large fluctuations in environmental parameters such as salinity and temperature.

The low COI intraspecific diversity in $H$. crispae $(0.7 \%)$ and the low interspecific diversity between $H$. crispae and Halobiotus from Ærø (0.7-1.0\%) is smaller than the amount of intraspecific variation (2-3\%) currently used in DNA barcoding studies to delimit species (Hebert et al. 2003). These data support the assumption that the specimens found at Nipisat Bay and Vellerup Vig belong to the same species. The low genetic diversity between $H$. crispae and Halobiotus from Ærø furthermore indicate that these specimens belong to the same species. Our studies clearly indicate that the Ærømaterial is not $H$. stenostomus as presented in Jørgensen \& Kristensen (2004), but a deep-water (6-8 meters) form of $H$. crispae.

\section{ACKNOWLEDGMENTS}

We thank the divers Martin McNaughton and Jonas Tomar, as well as Katrine Worsaae, for help with sample collections. We also express our thanks to the Organizing Committee of the 10th International Symposium on Tardigrada: Giovanni Pilato, Maria Grazia Binda, Oscar Lisi, University of Catania and Roberto Bertolani, Lorena Rebecchi, Roberto Guidetti, University of Modena and Reggio Emilia for putting together an inspiring program for the meeting. For information and loan of marine eutardigrades we are indebted to Jeanne Renaud-Mornant (Paris) and Robert P. Higgins (Smithsonian Institution, Washington D.C.). Finally, we gratefully acknowledge Roberto Bertolani for determining our fresh-water species of tardigrades. Funding came from The Danish Natural Science Research Council and the Villum Kann Rasmussen Foundation.

\section{REFERENCES}

Buchardt, B., P. Seaman, G., Stockmann, M.V.U., Wilken, L. Düwel, A. Kristiansen, C. Jenner, M.J. Whiticar, R.M. Kristensen, G.H. Petersen \& L. Thorbjørn. 1997. Submarine columns of ikaite tufa. Nature, 390: 129-130.

Dastych, H. 2004. Redescription of the glacier tardigrade Hypsibius janetscheki Ramazzotti, 1968 (Tardigrada) from the Nepal Himalayas. Entomol. Mitt. zool. Mus. Hamburg, 14: 181-194.

DeJong, R.J., J.A.T. Morgan, W.L. Paraense, J.-P. Pointier, M. Amarista, P.F.K. Ayeh-Kumi, A. Babiker, C.S. Barbosa, P. Brémond, A.P. Canese, C.P. de Souza, C. Dominguez, S. File, A. Gutierrez, R.N. Incani, T. Kawano, F. Kazibwe, J. Kpikpi, N.J.S. Lwambo, R. Mimpfoundi, F. Njiokou, J.N. Poda, M. Sene, L.E. Velásquez, M. Yong, C.M. Adema, B.V. Hofkin, G.M. Mkoji \& E.S. Loker. 2001. Evolutionary relationships and biogeography of Biomphalaria (Gastropoda: Planorbidae) with implications regarding its role as host of the human bloodfluke, Schistosoma mansoni. Mol. Biol. Evol., 18: 2225-2239.

Eibye-Jacobsen, J. 1997. Development, ultrastructure and function of the pharynx of Halobiotus crispae Kristensen, 1982 (Eutardigrada). Acta Zool., 78: 329-347.

Eibye-Jacobsen, J. 2001. Are the supportive structures of the tardigrade pharynx homologous throughout the entire group? J. Zool. Syst. Evol. Res., 39: 1-11.

Folmer, O., M. Black, W. Hoeh, R.A. Lutz \& R.C. Vrijenhoek. 1994. DNA primers for amplification of mitochondrial cytochrome c oxidase subunit I from diverse metazoan invertebrates. Mol. Mar. Biol. Biotech., 3: 294-299.

Garey, J.R., D.R. Nelson, L.Y. Mackey \& J. Li. 1999. Tardigrade phylogeny: Congruency of morphological and molecular evidence. Zool. Anz., 238: 205-210.

Giribet, G., S. Carranza, J. Baguña, M. Riutort \& C. Ribera. 1996. First molecular evidence for the Existence of a Tardigrada + Arthropoda clade. Mol. Biol. Evol., 13: 76-84.

Guidetti, R., D. Boshini, L. Rebecchi \& R. Bertolani. 2006. Encystment processes and the "Matrioshka-like stage" in a moss-dwelling and in a limnic species of eutardigrades (Tardigrada). Hydrobiologia, 558: 9-21.

Hansen, J. \& A.K. Katholm. 2002. A study of the genus Amphibolus from Disko Island with special attention on the life cycle of Amphibolus nebolusus (Eutardigrada: Eohypsibiidae). In: J.G. Hansen (Ed.), Arctic Biology Field Course Qeqertarsuaq 2002. Zoological Museum, University of Copenhagen, H.C.Ø. TRYK Copenhagen: 129-163. 
Hebert, P.D.N., A. Cywinska, S.L. Ball \& J.R. deWard. 2003. Biological identifications through DNA barcodes. Proc. $R$. Soc., 270: 313-321.

Jørgensen, M. \& R.M. Kristensen. 1991. Meiofauna investigations from Igloolik, N.W.T Arctic Canada. In: M. Jørgensen (Ed.), Arctic Biology Course 1989, Igloolik N.W.T. Canada. Zoological Museum University of Copenhagen, H.C.Ø. TRYK Copenhagen: 61-80.

Jørgensen, A. \& R.M. Kristensen. 2004. Molecular phylogeny of Tardigrada - investigation of the monophyly of Heterotardigrada. Mol. Phyl. Evol., 32: 666-670.

Jørgensen, A., N. Møbjerg \& R.M. Kristensen. 2007. A molecular study of the tardigrade Echiniscus testudo (Echiniscidae) reveals low DNA sequence diversity over a large geographical area. J. Limnol., 66(Suppl. 1): 77-83.

Kalt, M.R. \& B. Tandler. 1971. A study of fixation of early amphibian embryos for electron microscopy. J. Ultrastruct. Res., 36: 633-645.

Kinchin, I.M. 1994. The Biology of Tardigrades. Portland Press, London: $186 \mathrm{pp}$.

Kristensen, R.M. 1982. The first record of cyclomorphosis in Tardigrada based on a new genus and species from Arctic meiobenthos. Z. zool. Syst. Evolut.-forsch., 20: 249-270.
Maniatis, T., E.F. Fritsch \& J. Sambrook. 1982. Molecular Cloning: A Lab Manual. Cold Spring Harbor Laboratory, Cold Spring Harbor, New York: 387-389.

Markmann, M. 2000. Entwicklung und Anwendung einer 285 rDNA-Sequenzdatenbank zur Aufschlüsselung der Artenvielfalt limnischer Meiobenthosfauna im Hinblick auf den Einsatz moderner Chiptechnologie. Dissertation zur Erlangung des Doktorgrades der Naturwissenschaften der Fakultät für Biologie der Ludwig Maximilians Universität München, München: 193 pp.

McInnes, S.J. 1994. Zoogeographic distribution of terrestrial/freshwater tardigrades from current literature. J. Nat. Hist., 28: 257-352.

Møbjerg, N. \& C. Dahl. 1996. Studies on the morphology and ultrastructure of the Malpighian tubules of Halobiotus crispae Kristensen, 1982 (Eutardigrada). Zool. J. Linn. Soc., 116: 85-99.

Rasmussen, E. 1973. Systematics and ecology of the Isefjord marine fauna (Denmark). Ophelia, 11: 1-495.

Rebecchi, L. \& R. Bertolani. 1994. Maturative pattern of ovary and testis in eutardigrades of freshwater and terrestrial habitats. Invertebr. Reprod. Dev., 26: 107-118. 